\title{
Design and synthesis of ruthenium(II) OCO pincer type NHC complexes and their catalytic role towards the synthesis of amides
}

\author{
MUTHUKUMARAN NIRMALA and PERIASAMY VISWANATHAMURTHI* \\ Department of Chemistry, Periyar University, Salem 636 011, Tamil Nadu, India \\ e-mail: viswanathamurthi72@gmail.com
}

MS received 9 July 2015; revised 7 September 2015; accepted 9 September 2015

\begin{abstract}
The present contribution describes the synthesis and characterization of a family of robust ruthenium complexes, supported by a tridentate pincer ligand of the type bis-phenolate- $N$-heterocyclic carbene $\left.{ }^{{ }^{t \mathrm{Bu}}}(\mathrm{OCO})^{2-}\right](\mathrm{NHC})$. Ruthenium(II) complexes $(\mathbf{1 - 3})$ bearing bis-phenolate- $N$-heterocyclic carbene ligand were synthesized in good yields by the reaction of imidazolinium proligand $(\mathbf{H L})$ with metal precursors $\left[\mathrm{RuHCl}(\mathrm{CO})\left(\mathrm{EPh}_{3}\right)_{2}(\mathrm{~B})\right]\left(\mathrm{E}=\mathrm{P}\right.$ or $\mathrm{As} ; \mathrm{B}=\mathrm{PPh}_{3}, \mathrm{AsPh}_{3}$ or Py) by transmetalation from the corresponding silver carbene complex. All the Ru(II)-NHC complexes have been characterized by elemental analyses, spectroscopic methods as well as ESI mass spectrometry. Based on the spectral results, an octahedral geometry was assigned for all the complexes. The tridentate nature of the ${ }^{t \mathrm{Bu}}(\mathrm{OCO})^{2-}$ ligand as well as some level of steric protection provided by the ${ }^{t} \mathrm{Bu}$ groups may rationalize the excellent stability of the $\mathrm{Ru}-\mathrm{C}_{\text {carbene }}$ bond in the present systems. Moreover, for the explorations of catalytic potential of the synthesized compounds, all the three [Ru-NHC] complexes (1-3) were tested as catalysts for amidation of alcohols with amines. Notably, the complex 1 was found to be very efficient and versatile catalyst towards amidation of a wide range of alcohols with amines.
\end{abstract}

Keywords. Bis-phenolate- $N$-heterocyclic carbene ligand; [Ru-NHC] complexes; transmetalation; amidation.

\section{Introduction}

Recently, $N$-heterocyclic carbenes (NHCs) undoubtedly placed themselves on the front rows of the ligand matrix as developed and utilized successfully in the fields of fundamental organometallic chemistry, catalysis and materials. ${ }^{1}$ Their unique stereo-electronic features, such as strong metal- $\mathrm{C}_{\mathrm{NHC}}$ bonding, electronic/ steric tunability via the wingtips and excellent stability of the metal-NHC complexes toward heat, air and moisture, are considered as the keys to the observed success of this versatile class of ligands. We desired to critically evaluate the performances of a variety of transitionmetal-based $N$-heterocyclic carbene precatalysts, designed along these underlying hypotheses, in synthetically useful transformations. NHCs and phosphines have different $\sigma$-donating or $\pi$-back bonding properties. Both the NHC and the phosphorous based ancillary ligands can be tuned to increase the efficiency of the metal centre. ${ }^{2}$ Such ligands may significantly improve catalyst stability and their potential hemilability provide ease of generation of vacant coordination site and catalytically active species. It was naturally obvious that the $\mathrm{NHC}$ and the phosphorus ligands had to be mixed for

\footnotetext{
*For correspondence
}

the best of organometallic chemistry and homogeneous catalysis. ${ }^{3,4}$ In this area, our group has been actively engaged in the study on transition metal based aryloxy- $N$ heterocyclic carbene ligands and their catalytic activities in variety of organic transformations. ${ }^{5}$ Encouraged by our previous results of ruthenium(II) $o$-hydroxyaryl substituted bidentate NHC ligands $\left.\left({ }^{t \mathrm{Bu}}(\mathrm{OC})^{-}\right]\right)$in amide synthesis, ${ }^{6}$ the present work describes new ruthenium(II) complexes with a tridentate pincer ligand of the type bis-phenolate- $N$-heterocyclic carbene $\left[{ }^{t \mathrm{Bu}}(\mathrm{OCO})^{2-}\right]$, and their catalysis towards the synthesis of amides.

Amides are one of the most important and prolific functional groups, with a great importance in both research and industrial chemistry due to their prevalence in detergents, lubricants, biologically active compounds (scheme 1)..$^{7}$ The conventional strategy for amide bond formation involves reactions of activated carboxylic derivatives with amines. ${ }^{8}$ Alternative strategies toward the synthesis of amides are the Staudinger reaction, ${ }^{9}$ the Schmidt reaction, ${ }^{10}$ Beckmann rearrangement, ${ }^{11}$ aminocarbonylation of haloarenes, ${ }^{12}$ alkenes, ${ }^{13}$ and alkynes, ${ }^{14}$ oxidative amidation of aldehydes, ${ }^{15}$ hydrative amide synthesis with alkynes ${ }^{16}$ and the amidation of thio acids with azides. ${ }^{17}$ All of these methods have their own advantages, nonetheless they suffer from certain demerits, such as stoichiometric amount of the catalysts, harsh 


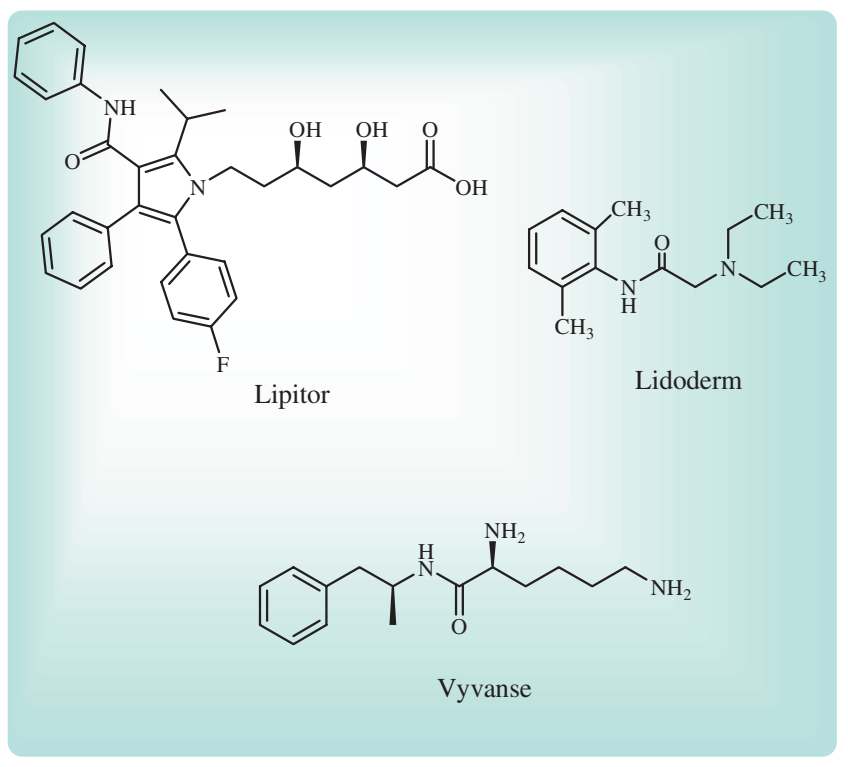

Scheme 1. Amide function in drug molecules.

reaction conditions, long reaction times, low selectivities and limited substrate scopes. Moreover, the separation and recycling of the catalysts from the reaction mass were difficult. Therefore there is a clear need for the synthesis of amides with more efficient, under neutral conditions and without the generation of waste, which is a challenging goal.

The current methods for amide formation are remarkably general but at the same time widely regarded as expensive and inelegant. A more environmentally friendly protocol for amide synthesis is the direct amidation of amines with alcohols where two molecules of dihydrogen are liberated. This unique transformation has been described once before where a ruthenium pincer complex was used for the direct coupling of sterically unhindered primary amines and alcohols, was made by the research group of Milstein et al. ${ }^{18}$ This direct catalytic conversion of alcohols and amines into amides and dihydrogen (molecular hydrogen) is a particularly desirable reaction due to its high atom efficiency, and this clean and simple reaction has inspired several other research groups to further develop the reactions using $\mathrm{Ru},{ }^{18,19} \mathrm{Rh}^{20}$ and $\mathrm{Ag}^{21}$ based catalytic systems. Among them, Ru complexes have been most extensively investigated. ${ }^{18,19 a}$ Particularly, the Madsen group showed that $\mathrm{Ru}(\mathrm{COD}) \mathrm{Cl}_{2}$ with $\mathrm{N}$-heterocyclic carbene (NHC) and phosphine ligands also catalyzed the formation of the amide rather than alkylation of the amine. ${ }^{22}$ Williams et al. employed $\left[\mathrm{Ru}(p \text {-cymene }) \mathrm{Cl}_{2}\right]_{2}$, phosphine ligand bis(diphenylphosphino)butane (dppb) and $\mathrm{Cs}_{2} \mathrm{CO}_{3}$ for the synthesis of secondary amides in presence of excess hydrogen acceptor 3-methyl-2-butanone. ${ }^{23}$ Hong's catalytic system involved $\left[\mathrm{Ru}(p \text {-cymene }) \mathrm{Cl}_{2}\right]_{2}, \mathrm{NHC}$ precursor, pyridine or acetonitrile and strong base $\mathrm{NaH}$. To unravel the nature of the in situ generated active catalyst, well defined Ru-NHC catalysts of the type ( $p$-cymene) $\mathrm{Ru}(\mathrm{NHC}) \mathrm{X}_{2}(\mathrm{X}=\mathrm{Cl}, \mathrm{I})$ were synthesized and their catalytic potential were evaluated. Only in the presence of two equivalents of strong base, these catalysts showed activity that match with in situ generated $\mathrm{Ru}-\mathrm{NHC}$ system. ${ }^{24}$

To circumvent the aforementioned drawbacks associated with in situ generated catalytic systems, during the course of our on-going efforts into developing catalytic syntheses of amide bonds and seeking of robust NHC-incorporating pincer-type ligands, the economic attractiveness and excellent functional group tolerance of ruthenium in homogeneous catalysis, ${ }^{24 \mathrm{f}}$ we developed a straightforward synthesis of the new family of well-defined, air and moisture-stable tridentate type bisphenolate ruthenium(II) $N$-heterocyclic carbene complexes. Herein, we report a full account on our studies of ruthenium(II) $N$-heterocyclic carbene catalysts in the dehydrogenative amide synthesis from alcohols with amines.

\section{Experimental}

\subsection{General comments}

All reactions involving the syntheses of metal complexes were carried out in oven- or flame dried glassware with magnetic stirrer under argon atmosphere with anhydrous solvents, using standard Schlenk techniques. Silver reactions were conducted in the absence of light. All commercial chemicals were used as purchased. Thin-layer chromatography (TLC) was performed on Merck 1.0555 aluminum sheets precoated with silica gel 60 F254, and the spots were visualized with UV light at $254 \mathrm{~nm}$ or under iodine. Column chromatography purifications were performed using Merck silica gel (100-200 mesh). Melting points were checked in open capillary tubes on a Technico micro heating table and are uncorrected.

\subsection{Materials}

The precursor complexes $\left[\mathrm{RuHCl}(\mathrm{CO})\left(\mathrm{PPh}_{3}\right)_{3}\right],{ }^{25}[\mathrm{Ru}$ $\left.\mathrm{HCl}(\mathrm{CO})\left(\mathrm{AsPh}_{3}\right)_{3}\right]^{26}$ and $\left[\mathrm{RuHCl}(\mathrm{CO})(\mathrm{Py})\left(\mathrm{PPh}_{3}\right)_{2}\right],{ }^{27}$ were prepared according to the previously published procedures.

\subsection{Spectroscopy}

Infrared spectra of the ligand and the metal complexes were recorded as $\mathrm{KBr}$ discs in the range of 4000-400 
$\mathrm{cm}^{-1}$ using a Nicolet Avatar model FT-IR spectrophotometer. ${ }^{1} \mathrm{H}(300.13 \mathrm{MHz}),{ }^{13} \mathrm{C}(75.47 \mathrm{MHz})$ and ${ }^{31} \mathrm{P}$ $(162 \mathrm{MHz})$ NMR spectra were taken in DMSO- $d_{6}$ or $\mathrm{CDCl}_{3}$ at room temperature with a Bruker AV400 instrument with chemical shifts relative to tetramethylsilane $\left({ }^{1} \mathrm{H},{ }^{13} \mathrm{C}\right)$ and $o$-phosphoric acid $\left({ }^{31} \mathrm{P}\right)$. Electrospray ionization mass spectra were recorded by liquid chromatography mass spectrometry quadrupole timeof-flight Micro Analyzer (Shimadzu) at SAIF, Panjab University, Chandigarh.

\subsection{Elemental analysis}

Microanalyses of carbon, hydrogen and nitrogen were carried out using a Vario EL III elemental analyzer at SAIF, Cochin, India.

\subsection{Synthesis of NHC ligand}

2.5a Synthesis of N,N'-Bis(2-Hydroxy-3,5-di-tert-butylphenyl)ethylenediamine: A suspension of 3,5-di-tertbutylcatechol $(3.0 \mathrm{~g} ; 13.5 \mathrm{mmol})$ in acetonitrile $(30 \mathrm{~mL})$ was treated with ethylenediamine $(0.41 \mathrm{~g} ; 6.75 \mathrm{mmol})$ in acetonitrile $(2 \mathrm{~mL})$ and the mixture was gently refluxed for $1 \mathrm{~h}$. After it was cooled to $20^{\circ} \mathrm{C}$ and stirred for a further $3 \mathrm{~h}$ during which time a colorless precipitate of $N, N^{\prime}$-bis(2-hydroxy-3,5-di-tert-butylphenyl) ethylenediamine formed which was filtered and thoroughly washed with $n$-hexane, and air-dried. Yield: 2.0 g. Yield: $64 \%$. White solid. M.p. $224^{\circ} \mathrm{C}$. Anal. Calcd for $\mathrm{C}_{30} \mathrm{H}_{48} \mathrm{~N}_{2} \mathrm{O}_{2}$ : C, 76.87; H, 10.32; N, 5.98\%. Found: $\mathrm{C}, 76.59 ; \mathrm{H}, 10.31 ; \mathrm{N}, 5.75 \%$. IR $\left(\mathrm{KBr}, \mathrm{cm}^{-1}\right): 3384$ (O-H), 1338 (C-O), $1576(\mathrm{~N}-\mathrm{C}-\mathrm{N}), 3117\left(\mathrm{CH}_{\mathrm{C}=\mathrm{C}}\right) .{ }^{1} \mathrm{H}$ NMR $\left(300.13 \mathrm{MHz}, \mathrm{DMSO}-d_{6}\right) \delta=1.24(\mathrm{~s}, 9 \mathrm{H}$, $\left.\mathrm{C}\left(\mathrm{CH}_{3}\right)_{3}\right), 1.22\left(\mathrm{~s}, 9 \mathrm{H}, \mathrm{C}\left(\mathrm{CH}_{3}\right)_{3}\right), 1.35\left(\mathrm{~s}, 9 \mathrm{H}, \mathrm{C}\left(\mathrm{CH}_{3}\right)_{3}\right)$, 1.39 (s, 9H, $\left.\mathrm{C}\left(\mathrm{CH}_{3}\right)_{3}\right), 3.29$ (s, 4H, $\left.\mathrm{CH}_{2}\right), 4.69$ (s, 2H, $\mathrm{NH}), 6.56(\mathrm{~d}, \mathrm{~J}=2.2 \mathrm{~Hz}, 2 \mathrm{H}, \operatorname{Ar}-\mathrm{H}), 6.59(\mathrm{~d}, \mathrm{~J}=$ $2.2 \mathrm{~Hz}, 2 \mathrm{H}, \mathrm{j}, \mathrm{Ar}-\mathrm{H}), 7.29$ (s, 1H, C-OH), 7.39 (s, 1H, $\mathrm{C}-\mathrm{OH}) .{ }^{13} \mathrm{C}$ NMR $\left(75.47 \mathrm{MHz}, \mathrm{DMSO}-d_{6}\right) \delta=29.81$ $\left(3 \mathrm{C}, \mathrm{C}\left(\mathrm{CH}_{3}\right)_{3}\right), 31.53\left(3 \mathrm{C}, \mathrm{C}\left(\mathrm{CH}_{3}\right)_{3}\right), 31.54(3 \mathrm{C}$, $\left.\mathrm{C}\left(\mathrm{CH}_{3}\right)_{3}\right), 31.67\left(3 \mathrm{C}, \mathrm{C}\left(\mathrm{CH}_{3}\right)_{3}\right), 34.21\left(1 \mathrm{C}, \mathrm{C}\left(\mathrm{CH}_{3}\right)_{3}\right)$, $34.55\left(1 \mathrm{C}, \mathrm{C}\left(\mathrm{CH}_{3}\right)_{3}\right), 35.37\left(1 \mathrm{C}, \mathrm{C}\left(\mathrm{CH}_{3}\right)_{3}\right), 35.68(1 \mathrm{C}$, $\left.\mathrm{C}\left(\mathrm{CH}_{3}\right)_{3}\right), 43.2\left(\mathrm{C}, \mathrm{CH}_{2}\right), 43.4\left(\mathrm{C}, \mathrm{CH}_{2}\right), 110.19(\mathrm{C})$, $111.64(\mathrm{C}), 123.21$ (C), 124.11 (C), 132.40 (C), 136.61 (C), 138.42 (C), 140.28 (C), 140.81 (C), 142.63 (C), 149.79 (C, C-O), 149.51 (C, C-O).

2.5b Synthesis of 1,3-bis(3,5-di-tert-butyl-2-hydroxyphenyl)imidazolinium chloride HL: HL was synthesized similar to the literature procedure,${ }^{28}$ which reported the synthesis of the similar compound $N, N$-bis(3,5di-tert-butyl-2-hydroxyphenyl)imidazolinium chloride.
Concentrated $\mathrm{HCl}(1.1 \mathrm{~mL}, 11 \mathrm{mmol})$ was added dropwise to a stirred solution of $N, N^{\prime}$-bis(2-hydroxy-3,5di-tert-butylphenyl)ethylenediamine $(2.34 \mathrm{~g}, 5 \mathrm{mmol}$, $25 \mathrm{~mL}$ of methanol) for $30 \mathrm{~min}$. Then the solvent was evaporated under reduced pressure, leaving a white solid in the flask. $\mathrm{HC}(\mathrm{OEt})_{3}(15 \mathrm{~mL})$ was added and refluxed at $120^{\circ} \mathrm{C}$ overnight. After the mixture was cooled and stood for 1 day, white crystalline solid was filtered and washed three times with hexane. Yield: $74 \%$. White solid. M.p. $264^{\circ} \mathrm{C}$. Anal. Calcd for $\mathrm{C}_{31} \mathrm{H}_{45} \mathrm{~N}_{2} \mathrm{O}_{2} \mathrm{Cl}: \mathrm{C}, 72.27 ; \mathrm{H}, 9.20 ; \mathrm{N}, 5.44 \%$. Found: C, 72.54; H, 9.41; N, $5.24 \%$. IR $\left(\mathrm{KBr}, \mathrm{cm}^{-1}\right): 3386$ $(\mathrm{O}-\mathrm{H}), 1336(\mathrm{C}-\mathrm{O}), 1541(\mathrm{~N}-\mathrm{C}-\mathrm{N}), 3116\left(\mathrm{CH}_{\mathrm{C}=\mathrm{C}}\right) .{ }^{1} \mathrm{H}$ $\operatorname{NMR}\left(300.13 \mathrm{MHz}, \mathrm{CDCl}_{3}\right) \delta=1.28\left(\mathrm{~s}, 9 \mathrm{H}, \mathrm{C}\left(\mathrm{CH}_{3}\right)_{3}\right)$, $1.21\left(\mathrm{~s}, 9 \mathrm{H}, \mathrm{C}\left(\mathrm{CH}_{3}\right)_{3}\right), 1.43\left(\mathrm{~s}, 9 \mathrm{H}, \mathrm{C}\left(\mathrm{CH}_{3}\right)_{3}\right), 1.39$ (s, 9H, C( $\left.\left(\mathrm{CH}_{3}\right)_{3}\right), 7.38$ (d, J = $1.8 \mathrm{~Hz}, 1 \mathrm{H}$, imi-H), 7.25 $(\mathrm{d}, \mathrm{J}=1.8 \mathrm{~Hz}, 1 \mathrm{H}$, imi-H), $7.41(\mathrm{~d}, \mathrm{~J}=2.2 \mathrm{~Hz}, 1 \mathrm{H}$, Ar-H), $7.48(\mathrm{~d}, \mathrm{~J}=2.2 \mathrm{~Hz}, 1 \mathrm{H}, \operatorname{Ar}-\mathrm{H}), 7.62(\mathrm{~d}, \mathrm{~J}=$ $2.2 \mathrm{~Hz}, 1 \mathrm{H}, \mathrm{Ar}-\mathrm{H}), 7.64(\mathrm{~d}, \mathrm{~J}=2.2 \mathrm{~Hz}, 1 \mathrm{H}, \mathrm{Ar}-\mathrm{H})$, $9.31(\mathrm{~s}, 1 \mathrm{H}, \mathrm{C}-\mathrm{OH}), 9.34$ (s, 1H, C-OH), $9.87(\mathrm{~s}, 1 \mathrm{H}$, $\mathrm{NCHN}) .{ }^{13} \mathrm{C} \mathrm{NMR}\left(75.47 \mathrm{MHz}, \mathrm{CDCl}_{3}\right) \delta=29.94(3 \mathrm{C}$, $\left.\mathrm{C}\left(\mathrm{CH}_{3}\right)_{3}\right), 30.15\left(3 \mathrm{C}, \mathrm{C}\left(\mathrm{CH}_{3}\right)_{3}\right), 31.45\left(3 \mathrm{C}, \mathrm{C}\left(\mathrm{CH}_{3}\right)_{3}\right)$, $31.42\left(3 \mathrm{C}, \mathrm{C}\left(\mathrm{CH}_{3}\right)_{3}\right), 34.33\left(1 \mathrm{C}, \mathrm{C}\left(\mathrm{CH}_{3}\right)_{3}\right), 35.26(1 \mathrm{C}$, $\left.\mathrm{C}\left(\mathrm{CH}_{3}\right)_{3}\right), 35.32\left(1 \mathrm{C}, \mathrm{C}\left(\mathrm{CH}_{3}\right)_{3}\right), 35.47\left(1 \mathrm{C}, \mathrm{C}\left(\mathrm{CH}_{3}\right)_{3}\right)$, 110.24 (C), 111.81 (C), 119.91 (C, imi-C), 121.34 (C, imi-C), 122.30 (C), 123.42 (C), 132.35 (C), 136.52 (C), 137.31 (C), 138.02 (C, NCHN), 140.36 (C), 140.79 (C), 142.54 (C), 149.61 (C, C-O), 149.82 (C, C-O). ESI-MS $(\mathrm{m} / \mathrm{z})$ : calcd. $477.70[\mathrm{M}-\mathrm{Cl}]^{+}$. Found, $477.81[\mathrm{M}-\mathrm{Cl}]^{+}$

\subsection{General procedure for the synthesis of Ruthenium (II)-N-heterocyclic carbene complexes (1-3)}

The milder conditions of the 'transmetalation' pathway make it an attractive choice for the synthesis of ruthenium complexes. ${ }^{29} \mathrm{~N}, \mathrm{~N}$-bis(3,5-di-tert-butyl-2hydroxyphenyl)imidazolinium ligand HL ( $2 \mathrm{mmol}$ ) was dissolved in $25 \mathrm{~mL}$ of dichloromethane and silver(I) oxide ( $1 \mathrm{mmol}$ ) was added, then the mixture was stirred for $24 \mathrm{~h}$ at room temperature under argon atmosphere. The unreacted $\mathrm{Ag}_{2} \mathrm{O}$ was filtered through a plug of Celite, and in most cases the solution was directly applied for further synthetic steps. The product can be isolated by removing the solvent under reduced pressure to give a solid, stable to oxygen and water. $[\mathrm{RuHCl}(\mathrm{CO})$ $\left.\left(\mathrm{EPh}_{3}\right)_{2}(\mathrm{~B})\right]\left(\mathrm{E}=\mathrm{P}\right.$ or $\mathrm{As} ; \mathrm{B}=\mathrm{PPh}_{3}, \mathrm{AsPh}_{3}$ or $\left.\mathrm{Py}\right)$ $(1 \mathrm{mmol})$ was taken up in $5 \mathrm{~mL}$ of dichloromethane and added to a solution of $\mathrm{Ag}$ complex in $10 \mathrm{~mL}$ of $\mathrm{CH}_{2} \mathrm{Cl}_{2}$. A white precipitate $(\mathrm{AgCl})$ formed, and the mixture was stirred overnight at room temperature. After filtration in air, the solvent was removed in vacuum to give an olive green waxy substance. The waxy substance was 
triturated with diethyl ether. The final compound is stable in air. The crude product was purified by column chromatography $\left(\mathrm{SiO}_{2}, 100-200\right.$ mesh). Elution with dichloromethane/acetone (10:1) afforded the separation of a yellow band that contained the desired product.

2.6a Compound (1): Yield: $81 \%$. Yellow solid. M.p. $208^{\circ} \mathrm{C}$. Anal. Calcd for $\mathrm{C}_{68} \mathrm{H}_{74} \mathrm{~N}_{2} \mathrm{O}_{3} \mathrm{P}_{2} \mathrm{Ru}: \mathrm{C}, 72.25 ; \mathrm{H}$, $6.60 ; \mathrm{N}, 2.48 \%$. Found: C, 72.47; H, 6.81; N, $2.22 \%$. IR $\left(\mathrm{KBr}, \mathrm{cm}^{-1}\right): 1938(\mathrm{C} \equiv \mathrm{O}), 1617(\mathrm{C}=\mathrm{C}), 1572(\mathrm{~N}-$ C-N), 1456 (C-C), 1412 (C-O). ${ }^{1} \mathrm{H}$ NMR (300.13 MHz, $\left.\mathrm{CDCl}_{3}\right) \delta=1.33\left(\mathrm{~s}, 18 \mathrm{H}, \mathrm{C}\left(\mathrm{CH}_{3}\right)_{3}\right), 1.35(\mathrm{~s}, 18 \mathrm{H}$, $\left.\mathrm{C}\left(\mathrm{CH}_{3}\right)_{3}\right), 7.02(\mathrm{~d}, \mathrm{~J}=2.3 \mathrm{~Hz}, 1 \mathrm{H}, \operatorname{Ar}-\mathrm{H}), 7.22(\mathrm{~d}, \mathrm{j}$ $=2.3 \mathrm{~Hz}, 1 \mathrm{H}$, Ar- $\mathrm{H}), 7.31(\mathrm{~d}, \mathrm{~J}=1.8 \mathrm{~Hz}, 1 \mathrm{H}$, imi$\mathrm{H}), 7.31(\mathrm{~d}, \mathrm{~J}=1.8 \mathrm{~Hz}, 1 \mathrm{H}, \mathrm{imi}-\mathrm{H}), 7.68(\mathrm{~d}, \mathrm{~J}=2.3$ $\mathrm{Hz}, 1 \mathrm{H}, \mathrm{Ar}-\mathrm{H}), 7.72$ (d, J = 2.3 Hz, 1H, Ar-H), 7.33$7.40\left(\mathrm{~m}, 15 \mathrm{H}, \mathrm{PPh}_{3}\right), 7.65-7.74\left(\mathrm{~m}, 15 \mathrm{H}, \mathrm{PPh}_{3}\right) \cdot{ }^{13} \mathrm{C}$ NMR $\left(75.47 \mathrm{MHz}, \mathrm{CDCl}_{3}\right) \delta=29.32\left(6 \mathrm{C}, \mathrm{C}\left(\mathrm{CH}_{3}\right)_{3}\right)$, $31.40\left(6 \mathrm{C}, \mathrm{C}\left(\mathrm{CH}_{3}\right)_{3}\right), 34.21\left(2 \mathrm{C}, \mathrm{C}\left(\mathrm{CH}_{3}\right)_{3}\right), 35.43(2 \mathrm{C}$, $\left.\mathrm{C}\left(\mathrm{CH}_{3}\right)_{3}\right), 110.81(\mathrm{C}), 111.92(\mathrm{C}), 120.19$ (C, imi-C), 121.42 (C, imi-C), 123.61 (C), 124.81 (C), 125.91, 126.71, 128.34, $129.6\left(\mathrm{PPh}_{3}\right), 132.46(\mathrm{C}), 135.81(\mathrm{C})$, 138.20 (C), 139.20 (C), 140.84 (C), 141.91 (C), 148.12 (C, C-O), 148.32 (C, C-O), 186.34 (Ru-C carbene $), 201.46$ $(\mathrm{C} \equiv \mathrm{O}) .{ }^{31} \mathrm{P}$ NMR $\left(162 \mathrm{MHz}, \mathrm{CDCl}_{3}\right): \delta=45.78$ $\& 46.25\left(2 \mathrm{~s}, 2 \mathrm{PPh}_{3}\right)$. ESI-MS $(\mathrm{m} / z)$ : calcd. 1130.34 . Found, 1130.10.

2.6b Compound (2): Yield: 79\%. Yellow solid. M.p. $212^{\circ} \mathrm{C}$. Anal. Calcd for $\mathrm{C}_{68} \mathrm{H}_{74} \mathrm{~N}_{2} \mathrm{O}_{3} \mathrm{As}_{2} \mathrm{Ru}$ : C, 67.04; H, 6.12; N, 2.30\%. Found: C, 67.39; H, 6.42; N, 2.04\%. IR $\left(\mathrm{KBr}, \mathrm{cm}^{-1}\right): 1934(\mathrm{C} \equiv \mathrm{O}), 1614(\mathrm{C}=\mathrm{C}), 1576(\mathrm{~N}-$ C-N), 1452 (C-C), 1410 (C-O). ${ }^{1} \mathrm{H}$ NMR (300.13 MHz, $\left.\mathrm{CDCl}_{3}\right) \delta=1.31\left(\mathrm{~s}, 18 \mathrm{H}, \mathrm{C}\left(\mathrm{CH}_{3}\right)_{3}\right), 1.37(\mathrm{~s}, 18 \mathrm{H}$, $\left.\mathrm{C}\left(\mathrm{CH}_{3}\right)_{3}\right), 7.13(\mathrm{~d}, \mathrm{~J}=2.3 \mathrm{~Hz}, 1 \mathrm{H}, \mathrm{Ar}-\mathrm{H}), 7.26(\mathrm{~d}, \mathrm{j}=$ $2.3 \mathrm{~Hz}, 1 \mathrm{H}, \mathrm{Ar}-\mathrm{H}), 7.28$ (d, J = $1.8 \mathrm{~Hz}, 1 \mathrm{H}$, imi-H), $7.34(\mathrm{~d}, \mathrm{~J}=1.8 \mathrm{~Hz}, 1 \mathrm{H}$, imi-H), $7.71(\mathrm{~d}, \mathrm{~J}=2.3 \mathrm{~Hz}$, $1 \mathrm{H}, \mathrm{Ar}-\mathrm{H}), 7.74$ (d, J = 2.3 Hz, 1H, Ar-H), 7.33-7.42 $\left(\mathrm{m}, 15 \mathrm{H}, \mathrm{PPh}_{3}\right), 7.68-7.75\left(\mathrm{~m}, 15 \mathrm{H}, \mathrm{PPh}_{3}\right) .{ }^{13} \mathrm{C} \mathrm{NMR}$ $\left(75.47 \mathrm{MHz}, \mathrm{CDCl}_{3}\right) \delta=29.51\left(6 \mathrm{C}, \mathrm{C}\left(\mathrm{CH}_{3}\right)_{3}\right)$, $31.46\left(6 \mathrm{C}, \mathrm{C}\left(\mathrm{CH}_{3}\right)_{3}\right), 34.33\left(2 \mathrm{C}, \mathrm{C}\left(\mathrm{CH}_{3}\right)_{3}\right), 35.53(2 \mathrm{C}$, $\left.\mathrm{C}\left(\mathrm{CH}_{3}\right)_{3}\right), 110.74(\mathrm{C}), 111.81(\mathrm{C}), 120.17$ (C, imi-C), 121.63 (C, imi-C), 123.69 (C), 124.82 (C), 125.96, 126.71, 128.42, 129.35, 130.21, $131.51\left(\mathrm{PPh}_{3}\right), 132.39$ (C), 135.76 (C), 138.51 (C), 139.40 (C), 140.73 (C), 141.87 (C), 148.41 (C, C-O), 148.56 (C, C-O), 187.21 (Ru-C $\left.\mathrm{C}_{\text {carbene }}\right), 202.10(\mathrm{C} \equiv \mathrm{O})$. ESI-MS $(\mathrm{m} / \mathrm{z})$ : calcd. 1218.24. Found, 1218.47.

2.6c Compound (3): Yield : 83\%. Yellow solid. M.p. $217^{\circ} \mathrm{C}$. Anal. Calcd for $\mathrm{C}_{55} \mathrm{H}_{64} \mathrm{~N}_{3} \mathrm{O}_{3} \mathrm{PRu}$ : C, 69.74; $\mathrm{H}$, 6.81; N, 4.44\%. Found: C, 69.91; H, 6.98; N, 4.24. IR
$\left(\mathrm{KBr}, \mathrm{cm}^{-1}\right): 1936(\mathrm{C} \equiv \mathrm{O}), 1619(\mathrm{C}=\mathrm{C}), 1574(\mathrm{~N}-\mathrm{C}-$ $\mathrm{N}), 1454$ (C-C), 1412 (C-O). ${ }^{1} \mathrm{H}$ NMR (300.13 MHz, $\left.\mathrm{CDCl}_{3}\right) \delta=1.34\left(\mathrm{~s}, 18 \mathrm{H}, \mathrm{C}\left(\mathrm{CH}_{3}\right)_{3}\right), 1.38(\mathrm{~s}, 18 \mathrm{H}$, $\left.\mathrm{C}\left(\mathrm{CH}_{3}\right)_{3}\right), 7.21(\mathrm{~d}, \mathrm{~J}=2.3 \mathrm{~Hz}, 1 \mathrm{H}, \mathrm{Ar}-\mathrm{H}), 7.24(\mathrm{~d}, \mathrm{~J}=$ $2.3 \mathrm{~Hz}, 1 \mathrm{H}, \mathrm{Ar}-\mathrm{H}), 7.29$ (d, J = $1.8 \mathrm{~Hz}, 1 \mathrm{H}, \mathrm{imi}-\mathrm{H})$, $7.38(\mathrm{~d}, \mathrm{~J}=1.8 \mathrm{~Hz}, 1 \mathrm{H}$, imi-H), 7.36-7.55 (m, $15 \mathrm{H}$, $\left.\mathrm{PPh}_{3}\right), 7.56\left(\mathrm{td}, \mathrm{J}=6.6 \mathrm{~Hz}, \mathrm{~J}=1.2 \mathrm{~Hz}, 2 \mathrm{H}, \mathrm{CH}_{\mathrm{py}}\right.$ ), $7.61(\mathrm{~d}, \mathrm{~J}=2.3 \mathrm{~Hz}, 1 \mathrm{H}, \mathrm{Ar}-\mathrm{H}), 7.64\left(\mathrm{~s}, 2 \mathrm{H}, \mathrm{CH}_{\mathrm{py}}\right)$, $7.68(\mathrm{~d}, \mathrm{~J}=2.3 \mathrm{~Hz}, 1 \mathrm{H}, \mathrm{Ar}-\mathrm{H}), 7.95(\mathrm{tt}, \mathrm{J}=6.6$ $\left.\mathrm{Hz}, \mathrm{J}=1.2 \mathrm{~Hz}, 1 \mathrm{H}, \mathrm{CH}_{\mathrm{py}}\right), 9.19(\mathrm{~d}, \mathrm{~J}=6.6 \mathrm{~Hz}, 2 \mathrm{H}$, $\left.\mathrm{NCH}_{\mathrm{py}}\right) .{ }^{13} \mathrm{C} \mathrm{NMR}\left(75.47 \mathrm{MHz}, \mathrm{CDCl}_{3}\right) \delta=29.14(6 \mathrm{C}$, $\left.\mathrm{C}\left(\mathrm{CH}_{3}\right)_{3}\right), 32.37\left(6 \mathrm{C}, \mathrm{C}\left(\mathrm{CH}_{3}\right)_{3}\right), 34.31\left(2 \mathrm{C}, \mathrm{C}\left(\mathrm{CH}_{3}\right)_{3}\right)$, $35.62\left(2 \mathrm{C}, \mathrm{C}\left(\mathrm{CH}_{3}\right)_{3}\right), 110.91(\mathrm{C}), 111.43(\mathrm{C}), 120.24$ (C, imi-C), 121.54 (C, imi-C), 123.54 (C), 124.35 (C), 127.93, 127.64, $127.31\left(\mathrm{PPh}_{3}\right), 128.81,128.64,128.21$ (Py) 132.41 (C), 135.68 (C), 138.42 (C), 139.61 (C), 140.51 (C), 141.73 (C), 148.39 (C, C-O), 148.63 (C, CO), 187.70 (Ru- $\left.\mathrm{C}_{\text {carbene }}\right), 203.21(\mathrm{C} \equiv \mathrm{O}) .{ }^{31} \mathrm{P}$ NMR (162 $\left.\mathrm{MHz}, \mathrm{CDCl}_{3}\right): \delta=47.41\left(\mathrm{~s}, \mathrm{PPh}_{3}\right)$. ESI-MS $(m / z)$ : calcd. 947.60. Found, 947.30

\subsection{Representative procedure for amidation reaction}

$1 \mathrm{mmol}$ alcohol, $1.2 \mathrm{mmol}$ amine, $5 \mathrm{~mol} \% \mathrm{NaH}$ and 1 mol\% of [Ru-NHC] catalyst (1-3) were introduced successively in Schlenk tube and the mixture was heated at $100^{\circ} \mathrm{C}$ in toluene under an argon atmosphere for 8 h. The reaction mixture was cooled to room temperature and the solvent was removed under vacuum and the residue was purified by silica gel (100-200 mesh) column chromatography to afford the amide. The resulting amides were identified by comparison of the ${ }^{1} \mathrm{H}$ and ${ }^{13} \mathrm{C}$ NMR data with those previously reported ${ }^{22-24}$ (ESI $\dagger$ ).

\section{Results and Discussion}

\subsection{Synthesis of ligand precursor and metal complexes}

The NHC proligand 1,3-bis(3,5-di-tert-butyl-2-hydroxyphenyl)imidazolinium chloride (HL) was prepared according to a literature report ${ }^{28}$ using a classical procedure $\left(\mathrm{HCl} \text { and then }(\mathrm{EtO})_{3} \mathrm{CH}\right)^{30}$ (scheme 2). The synthetic plan to reach the novel ruthenium complexes disclosed herein was initially attempted by deprotonation of imidazolium salts with a strong base $\left(\mathrm{KO}^{t} \mathrm{Bu}\right.$ or KHMDS) in THF followed by the addition of metal precursor, but the products were not obtained quantitatively. Hence, the most widely used method of deprotonation by the use of silver base has been used in the syntheses of $N$-heterocylic carbene complexes. Among the various silver bases, $\mathrm{Ag}_{2} \mathrm{O}$ is most commonly used as a metal base. Treatment with $\mathrm{Ag}_{2} \mathrm{O}$ which acts as 


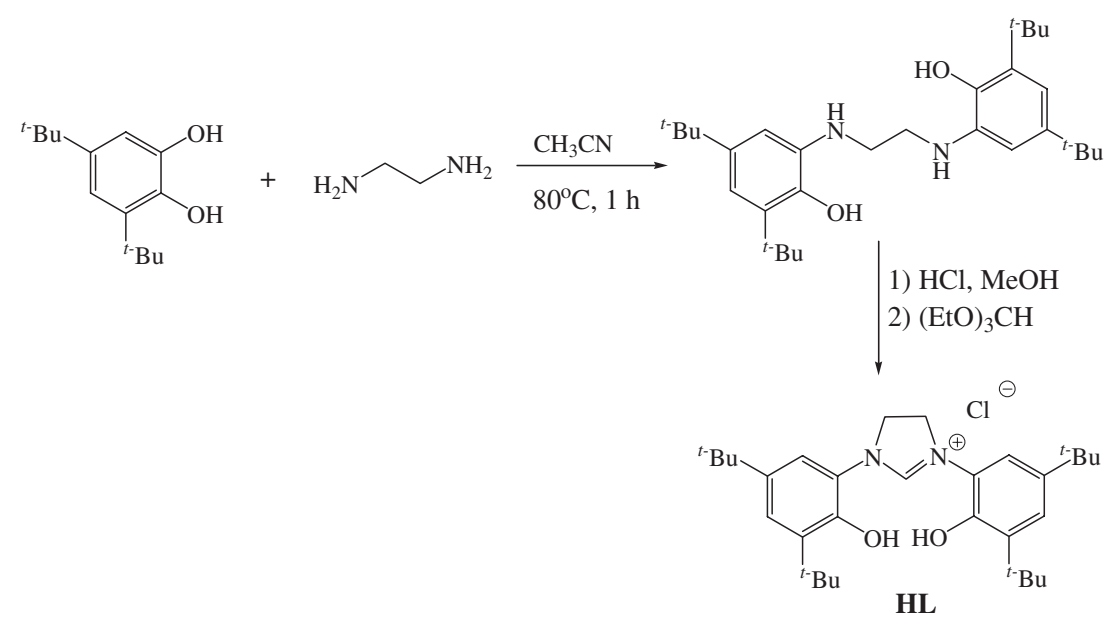

Scheme 2. Synthesis of NHC ligand.

both base and halide scavenger, under light-free conditions in $\mathrm{CH}_{2} \mathrm{Cl}_{2}$ at room temperature afforded the silver carbene complexes. This method is the direct path for the preparation of the Ru-complexes involving a transmetalation step using the corresponding NHCsilver(I) complex of the tridentate ligand (HL). This approach has also earlier been utilized successfully for a wide variety of transition metals and proved to be a convenient method over other methods under certain conditions. ${ }^{29}$ The special attributes of the $\mathrm{Ag}_{2} \mathrm{O}$ technique, such as (a) reactions can be carried out in air, (b) solvent pre-treatments are not required, (c) no additional base is needed, (d) deprotonation usually takes place at $\mathrm{C}_{2}$-carbene, and (e) tolerance of $\mathrm{Ag}_{2} \mathrm{O}$ towards some active hydrogen atoms, were considered as some of the reasons to highlight this technique in metalNHC chemistry. The ruthenation was accomplished by metalation with $\mathrm{Ag}_{2} \mathrm{O}$ to form intermediate silver carbene complexes and subsequent transmetalation ${ }^{31}$ with $\left[\operatorname{RuHCl}(\mathrm{CO})\left(\mathrm{EPh}_{3}\right)_{2}(\mathrm{~B})\right]\left(\mathrm{E}=\mathrm{P}\right.$ or $\mathrm{As} ; \mathrm{B}=\mathrm{PPh}_{3}$, $\mathrm{AsPh}_{3}$ or Py) indeed, as summarized in scheme 3 . The obtained silver complexes are highly stable in air and moisture, and soluble in $\mathrm{CH}_{2} \mathrm{Cl}_{2}, \mathrm{CHCl}_{3}, \mathrm{CH}_{3} \mathrm{CN}$, DMSO and insoluble in diethyl ether. The NHC-silver complexes are light-sensitive to solution, but lightstable as solid. The disappearance of ${ }^{1} \mathrm{H}$ NMR signal of the imidazolium ring ( $\mathrm{NCHN})$ along with the appearance of a diagnostic silver-bound carbene (NCN-Ag) peak at $\sim 164 \mathrm{ppm}$ in the ${ }^{13} \mathrm{C}$ NMR spectra are the characteristic features of the silver carbene complex. The ruthenium(II) complexes (1-3) supported by the aryloxide NHC ligand were isolated upon precipitation with diethyl ether as brown powder in $>90 \%$ yield and they are extremely soluble in $\mathrm{CH}_{2} \mathrm{Cl}_{2}, \mathrm{CHCl}_{3}$, THF and DMSO. However, they are sparsely soluble in $\mathrm{CH}_{3} \mathrm{CN}$, but hardly soluble in $\mathrm{Et}_{2} \mathrm{O}$, hexane and pentane. In fact,<smiles>CC(C)(C)Cc1cc(C(C)(C)C)cc(N2CCN(c3cc(C(C)(C)C)cc(C(C)(C)C)c3O)C2)c1O</smiles>

i) $\mathrm{Ag}_{2} \mathrm{O}, \mathrm{CH}_{2} \mathrm{Cl}_{2}, 24$ h, r.t

ii) $\left[\mathrm{RuHCl}(\mathrm{CO})\left(\mathrm{EPh}_{3}\right)_{2}(\mathrm{~B})\right], 24 \mathrm{~h}$, r.t

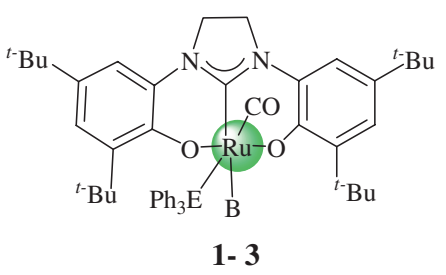

$\mathrm{E}=\mathrm{P}, \mathrm{B}=\mathrm{PPh}_{3}(\mathbf{1}), \mathrm{E}=\mathrm{As}, \mathrm{B}=\mathrm{AsPh}_{3}(\mathbf{2}), \mathrm{E}=\mathrm{P}, \mathrm{B}=\mathrm{Py}(\mathbf{3})$

Scheme 3. General synthesis of [Ru-NHC] complexes (1-3).

they were isolated by precipitation from the reaction mixture using $\mathrm{Et}_{2} \mathrm{O}$ during the course of their synthesis. All the complexes (1-3) were fully characterized by ${ }^{1} \mathrm{H}$, ${ }^{13} \mathrm{C}$ and ${ }^{31} \mathrm{P}$ NMR, mass spectra and elemental analyses. The analytical data $(\mathrm{C}, \mathrm{H}, \mathrm{N})$ of the $[\mathrm{Ru}-\mathrm{NHC}]$ complexes (1-3) are in good agreement with the proposed molecular formulae.

\subsection{Spectroscopy}

IR spectra of free ligand were compared with new complexes in order to confirm the coordination of ligand to ruthenium metal. The new [Ru-NHC] complexes (1-3) showed a $v_{\mathrm{CO}}$ stretch in the IR spectrum at $\sim 1936 \mathrm{~cm}^{-1}$, indicating considerable back bonding present in this 
ligand. ${ }^{32}$ The ligand showed a strong band in the region $1541 \mathrm{~cm}^{-1}$ due to $v_{\mathrm{N}-\mathrm{C}-\mathrm{N}}$. This band has been shifted to higher frequency $1572-1576 \mathrm{~cm}^{-1}$ in the metal complexes, indicating the coordination of ligand to metal through carbene carbon. In the spectra of free ligand, a strong band obtained around $1336 \mathrm{~cm}^{-1}$ was assigned to phenolic $\mathrm{C}-\mathrm{O}$ stretching, which has been shifted to a higher frequency $\left(\sim 1410 \mathrm{~cm}^{-1}\right)$ in complexes indicating the participation of phenolic oxygen in bonding. This has been further confirmed by the disappearance of the broad $v_{\mathrm{OH}}$ band around $3386 \mathrm{~cm}^{-1}$ in complexes due to the bonding of phenolic-OH group with ruthenium metal via deprotonation.

The generation of free carbene and subsequent formation of the [Ru-NHC] complexes were unambiguously confirmed by the absence of the ${ }^{1} \mathrm{H}$ NMR resonances of imidazolium $(\mathrm{NCHN})$ and phenolic $(\mathrm{C}-\mathrm{OH})$ protons. The imidazolium ring backbone signals appeared around 7.25-7.38 ppm. Furthermore, the spectra of all the complexes showed a series of signals for aromatic protons at 7.13-7.95 ppm. The spectra of the complexes showed a singlet at $1.28-1.38 \mathrm{ppm}$, which has been assigned to ${ }^{t} \mathrm{Bu}$ protons.

The ${ }^{13} \mathrm{C}$ NMR spectra showed the expected signals in the appropriate region. The ruthenium complexes showed their carbenic carbon resonances at $c a$ 186.30$187.70 \mathrm{ppm}$ (Ru-C $\left.\mathrm{C}_{\text {carbene }}\right)$, characteristic of the carbenic carbon bound to ruthenium. Normally, $\mathrm{Ru}-\mathrm{C}_{\text {carbene }}$ resonances of Ru-NHC complexes are found in the wide range of $171-197 \mathrm{ppm}^{33}$ The $\mathrm{C} \equiv \mathrm{O}$ carbon resonating at 201.46-203.21 ppm is comparable with earlier observations. The presence of peak in the region 148.12$149.82 \mathrm{ppm}$ has been assigned to aryloxy carbon. The signal observed at 110.24-141.91 ppm in the spectra of complexes is due to aromatic carbons.

${ }^{31} \mathrm{P}$ NMR spectra of the complexes were recorded to confirm the presence of triphenylphosphine groups coordinated to ruthenium center and to determine the configuration of triphenylphosphine groups. The two singlets appeared at $45.78-46.25 \mathrm{ppm}$ in the spectra of complex 1 indicated that the two triphenylphosphine ligands are $c i s$ to each other in these complex. However, the complex 3 exhibited only one signal at $47.41 \mathrm{ppm}$ consistent with the presence of one triphenylphosphine group.

The molecular ion peaks $\left(\mathrm{M}^{+}\right)$observed with $\mathrm{m} / \mathrm{z}$ values $479.81,1130.10,1218.47$ and 947.30 corresponding to the ligand $\mathrm{HL}$ and [Ru-NHC] complexes 1, 2 and 3, respectively, in the ESI-MS spectra of the ligand and complexes, supporting the proposed molecular formulae. Unfortunately, we have not yet obtained high-quality crystals of [Ru-NHC] complexes suitable for X-ray single crystal diffraction, suggesting that subtle structural factors are critical to stabilizing this species.

\subsection{Catalytic studies}

3.3a Catalytic amidation of alcohols with amines: Numerous reports have demonstrated that ruthenium complexes are good catalysts for the synthesis of amides. ${ }^{18 \mathrm{a}-18 \mathrm{~d}}$ In the formation of amides by direct coupling between alcohols and amines, $N$-heterocyclic carbene (NHC) ruthenium based catalysts have recently played an important role. ${ }^{18 \mathrm{e}}$ Notably, simple welldefined [Ru-NHC] complexes are among the best catalysts for this transformation, which can be performed using a wide variety of amines and alcohols. ${ }^{24 \mathrm{~d}}$ The use of NHC-based ligands seems to bring a series of advantages to the development of this catalytic reaction, because NHCs combine a number of attractive features. ${ }^{18 f-i}$ First, the azolium ligand precursor is stable toward oxidation. ${ }^{18 \mathrm{j}, \mathrm{k}}$ Second, the number of possible coordination modes of the carbene to the metal, paired with the large library of NHC-type ligands, may allow the electronic properties of the metal to be fine-tuned, with obvious implications for catalytic outcomes. Third, the carbene ligand displays a pronounced mesoionic character, ${ }^{181-\mathrm{n}}$ thus accommodating positive and negative partial charges in the same heterocycle. These latter properties may be the key for coordinating metal centers in different oxidation states. ${ }^{180}$ Thus, with the new carbene complexes in hand, their abilities to catalyze amidation of alcohols with amines were studied. In principle, the direct amidation of amines with alcohols are highly desired atom economical transformations that evolve hydrogen as a sole by-product with less waste than traditional amide synthesis. Herein, we report an unprecedented [Ru-NHC] catalyzed amidation of alcohols with amines.

\section{3b Evaluation of conditions for amidation reac-}

tions: At the start of our investigations, a screen was performed for a model reaction between benzyl alcohol with benzylamine and the results are depicted in table 1. Considering the pivotal role of base in promoting the formation of intermediates during the catalytic cycle, different bases including $\mathrm{NaOH}, \mathrm{K}_{2} \mathrm{CO}_{3}, \mathrm{KO}^{t} \mathrm{Bu}$, $\mathrm{NaH}, \mathrm{Cs}_{2} \mathrm{CO}_{3}, \mathrm{KOH}, \mathrm{NaO}^{t} \mathrm{Bu}$ and $\mathrm{Na}_{2} \mathrm{CO}_{3}$ were used. High yield of $\mathrm{N}$-benzylbenzamide was obtained when $\mathrm{NaH}$ was used as the base in these reactions at $100^{\circ} \mathrm{C}$ (table 1 , entry 3,4 ). To this end, we noticed that a strong base was required to promote the reaction. It is well known that the solvent can have profound effect on amidation reaction. We were interested in exploring 
Table 1. Screening of bases for amidation of benzyl alcohol with benzylamine ${ }^{\mathrm{a}}$.

\begin{tabular}{|c|c|c|}
\hline Entry & Base & Yield $(\%)^{\mathrm{b}}$ \\
\hline 1 & $\mathrm{NaOH}$ & 76 \\
\hline 2 & $\mathrm{~K}_{2} \mathrm{CO}_{3}$ & n.r \\
\hline 3 & $\mathrm{KO}^{t} \mathrm{Bu}$ & 82 \\
\hline 4 & $\mathrm{NaH}$ & 94 \\
\hline 5 & $\mathrm{Cs}_{2} \mathrm{CO}_{3}$ & n.r \\
\hline 6 & $\mathrm{KOH}$ & 78 \\
\hline 7 & $\mathrm{NaO}^{t} \mathrm{Bu}$ & 58 \\
\hline 8 & $\mathrm{Na}_{2} \mathrm{CO}_{3}$ & n.r \\
\hline
\end{tabular}

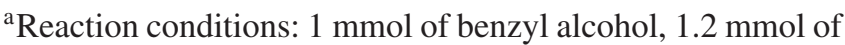
benzylamine, base (5 mol \%), catalyst $1(1 \mathrm{~mol} \%)$ in $3 \mathrm{~mL}$ of toluene at $100^{\circ} \mathrm{C}$.

${ }^{b}$ Yields were calculated after isolation of the amide product through short column chromatography using silica gel (100200 mesh).

the solvent-dependent differences in activity of catalyst 1 by carrying out the model reaction in the most frequently used solvents such as ethanol, THF, DMF, toluene, DMSO, xylene, 1,4-dioxane and benzene (table 2). Among them, aromatic hydrocarbon solvents such as toluene and xylene (table 2, entry 4, 6) were found to be better reaction media than polar aprotic (DMF, DMSO) (table 2, entry 3, 5) or protic solvents (EtOH) (table 2, entry 1), whereas THF proved completely futile (table 2, entry 2). Pleasingly, toluene was found to be the solvent choice, giving $94 \%$ yield in $8 \mathrm{~h}$, whereas benzene was inferior (table 2 , entry 8 ).

Table 2. Screening of solvents for amidation of benzyl alcohol with benzylamine ${ }^{\mathrm{a}}$.

\begin{tabular}{|c|c|c|}
\hline Entry & Solvent & Yield $(\%)^{\mathrm{b}}$ \\
\hline 1 & Ethanol & 20 \\
\hline 2 & $\mathrm{THF}$ & n.r \\
\hline 3 & DMF & 24 \\
\hline 4 & Toluene & 94 \\
\hline 5 & DMSO & 38 \\
\hline 6 & $o$-xylene & 72 \\
\hline 7 & 1,4-dioxane & $>10$ \\
\hline 8 & Benzene & 26 \\
\hline
\end{tabular}

${ }^{a}$ Reaction conditions: $1 \mathrm{mmol}$ of benzyl alcohol, $1.2 \mathrm{mmol}$ of benzylamine, $\mathrm{NaH}(5 \mathrm{~mol} \%)$, catalyst $1(1 \mathrm{~mol} \%)$ in $3 \mathrm{~mL}$ of solvent at $100^{\circ} \mathrm{C}$.

${ }^{b}$ Yields were calculated after isolation of the amide product through short column chromatography using silica gel (100200 mesh).
Table 3. Catalyst screening for amidation of benzyl alcohol with benzylamine ${ }^{\mathrm{a}}$.

\begin{tabular}{|c|c|c|c|c|}
\hline Entry & Catalyst & $\begin{array}{c}\text { Amount of } \\
\text { catalyst }(\mathrm{mol} \%)\end{array}$ & $\mathrm{TON}^{\mathrm{b}}$ & Yield $^{\mathrm{c}}$ \\
\hline 1 & 1 & $0.25 / 0.5 / 1$ & 288/170/94 & $72 / 85 / 94$ \\
\hline 2 & 2 & $0.25 / 0.5 / 1$ & $272 / 158 / 89$ & 68/79/89 \\
\hline 3 & 3 & $0.25 / 0.5 / 1$ & $332 / 180 / 91$ & $83 / 90 / 91$ \\
\hline
\end{tabular}

${ }^{a}$ Reaction conditions: $1 \mathrm{mmol}$ of alcohol, $1.2 \mathrm{mmol}$ of amine, $\mathrm{NaH}(5 \mathrm{~mol} \%)$, catalyst $(0.25-1 \mathrm{~mol} \%)$ in $3 \mathrm{~mL}$ of toluene.

b Turnover number $(\mathrm{TON})=(\mathrm{mmol}$ of product $) /(\mathrm{mmol}$ of catalyst) after time t. ${ }^{\mathrm{c}}$ Yields were calculated after isolation of the amide product through short column chromatography using silica gel (100-200 mesh).

3.3c Catalyst screening: We continued the amidation reaction optimization process after finding the need for a strong base to activate the [Ru-NHC] complex $\mathbf{1}$. The results are summarized in table 3 . Catalyst screening in the model reaction revealed that all the [Ru-NHC] complexes triggered the reaction. The results also indicate that lower catalyst loading lead to moderate yields, higher catalyst loadings lead to higher yields. Catalyst with triphenylphosphine exhibit higher activity compared to others. The $\sigma$-donating and $\pi$-bonding nature triphenylphosphine can be the responsible for the above observations. ${ }^{19 a}$ Triphenylarsine coligand is similar to triphenylphosphine in many aspects, a very good leaving group and also has good donor properties. This ligand stood next to triphenylphosphine and pyridine coligands. Hence, the order of catalytic activity with respect to coligands has been observed as $\mathrm{PPh}_{3}>\mathrm{Py}>\mathrm{AsPh}_{3}$.

The optimization process led us toward the determination of the best reaction conditions to evaluate the substrate scope. Catalysts 1-3 proved to be the most efficient complexes for amidation of alcohols with amines. Furthermore, the results showed that $1 \mathrm{~mol} \%$ catalyst in toluene was sufficient to push this reaction and the most suitable reaction temperature was $100^{\circ} \mathrm{C}$, given the high yield and shorter reaction time needed to complete the process.

\section{$3.4[\mathrm{Ru}-\mathrm{NHC}]$ catalyzed amide syntheses from alcohols and primary amines}

After we established the suitable reaction conditions, a number of structurally diverse alcohols and amines were coupled to evaluate the reliability of the reaction and the results are summarized in table 4. All the reactions proceeded smoothly and afforded the desired amide products in reasonable to excellent yields upon 
Table 4. [Ru-NHC] catalyzed amide synthesis from alcohols and primary amines ${ }^{\mathrm{a}}$.

$$
\mathrm{R} \mathrm{OH}+\mathrm{R}^{\prime}-\mathrm{NH}_{2} \underset{\substack{\mathrm{NaH}, \text { Toluene } \\ 100^{\circ} \mathrm{C}, 8 \mathrm{~h}}}{\stackrel{[\mathrm{Ru}-\mathrm{NHC}](1 \mathrm{~mol} \%)}{\longrightarrow}} \mathrm{R}_{\mathrm{H}}^{\mathrm{N}}-2 \mathrm{H}_{2}
$$

\begin{tabular}{|c|c|c|c|c|c|c|c|c|c|c|}
\hline \multirow[b]{2}{*}{ Entry } & \multirow[b]{2}{*}{ Amide } & \multicolumn{3}{|c|}{$\mathrm{TON}^{\mathrm{c}}$} & \multicolumn{3}{|c|}{$\mathrm{TOF}^{\mathrm{d}}$} & \multicolumn{3}{|c|}{ Yield $(\%)^{\mathrm{b}}$} \\
\hline & & 1 & 2 & 3 & 1 & 2 & 3 & 1 & 2 & 3 \\
\hline
\end{tabular}

1<smiles>O=C(NCc1ccccc1)c1ccccc1</smiles>

2<smiles>O=C(NCc1ccc(Cl)cc1)c1ccccc1</smiles>

3

4<smiles>O=C(Nc1ccccc1)c1ccccc1</smiles>

5

6<smiles>Cc1ccc(C(=O)NCc2ccccc2)cc1</smiles><smiles>Cc1ccc(CNC(=O)c2ccc(C)cc2)cc1</smiles>

92

$\begin{array}{lllllll}86 & 89 & 12 & 11 & 11 & 92 & 86\end{array}$

88

879

86

76

$\begin{array}{lllllllll}80 & 73 & 78 & 10 & 9 & 10 & 80 & 73 & 78\end{array}$

$\begin{array}{lllllllll}80 & 73 & 78 & 10 & 9 & 10 & 80 & 73 & 78\end{array}$

7<smiles>Cc1ccc(C(=O)NC2CCCCC2)cc1</smiles><smiles>Cc1ccc(C(=O)Nc2ccccc2)cc1</smiles> 
Table 4. (continued)

\begin{tabular}{|c|c|c|c|c|c|c|c|c|c|c|}
\hline \multirow[b]{2}{*}{ Entry } & \multirow[b]{2}{*}{ Amide } & \multicolumn{3}{|c|}{$\mathrm{TON}^{\mathrm{c}}$} & \multicolumn{3}{|c|}{$\mathrm{TOF}^{\mathrm{d}}$} & \multicolumn{3}{|c|}{ Yield $(\%)^{\mathrm{b}}$} \\
\hline & & 1 & 2 & 3 & 1 & 2 & 3 & 1 & 2 & 3 \\
\hline
\end{tabular}

9<smiles>COc1ccc(C(=O)NCc2ccccc2)cc1</smiles>

10<smiles>COc1ccc(C(=O)NCc2ccc(C)cc2)cc1</smiles>

11

13

14

15<smiles>COc1ccc(C(=O)Nc2ccccc2)cc1</smiles><smiles>O=C(NCc1ccccc1)c1ccc(F)cc1</smiles><smiles>CCCCCCCCCC(=O)NCc1ccccc1</smiles><smiles>CCCCCCCCC(=O)Nc1ccccc1</smiles>

12

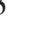

14

96

81

87

12

10

1196

93

79

79

72

10

8

$\begin{array}{lll}9 & 79 & 79\end{array}$

72

8

81

73

10

9

9

$81 \quad 81$

73

76

76

71

10

8

$\begin{array}{lll}9 & 76 & 76\end{array}$

71

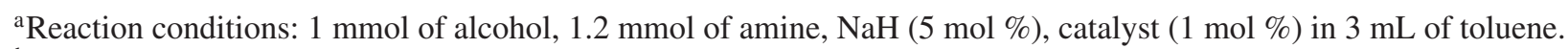

${ }^{b}$ Yields were calculated after isolation of the amide product through short column chromatography using silica gel (100-200 mesh).

${ }^{\mathrm{c}}$ Molar ratios of product formed with the catalyst used.

${ }^{\mathrm{d}} \mathrm{TOF}=\mathrm{TON} / \mathrm{time}(\mathrm{h})$

isolation. The results in table 4 demonstrate that the catalytic process is able to tolerate variety of functional groups and substituents including $\mathrm{CH}_{3}, \mathrm{OCH}_{3}$ and $\mathrm{F}$. Various amines underwent the reaction smoothly and gave rise to good to excellent product yields. Benzyl alcohol gave excellent conversions of the corresponding amides with benzylamine (table 4 , entry 1), $p$ methylbenzylamine (entry 2), cyclohexylamine (entry 3 ) and aniline (entry 4) with $1 \mathrm{~mol} \%$ of [Ru-NHC] catalysts 1-3. Similarly the amidation of $p$-methylbenzyl 
Table 5. [Ru-NHC] catalyzed amide synthesis from alcohols and secondary amines ${ }^{\mathrm{a}}$.

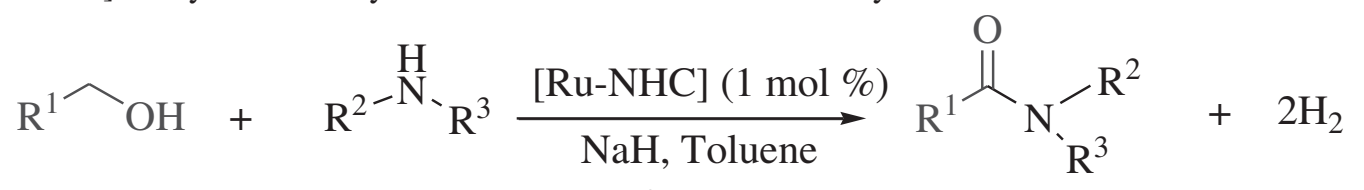

$100^{\circ} \mathrm{C}, 8 \mathrm{~h}$

\begin{tabular}{|c|c|c|c|c|c|c|c|c|c|c|}
\hline \multirow[b]{2}{*}{ Entry } & \multirow[b]{2}{*}{ Amide } & \multicolumn{3}{|c|}{$\mathrm{TON}^{\mathrm{c}}$} & \multicolumn{3}{|c|}{$\mathrm{TOF}^{\mathrm{d}}$} & \multicolumn{3}{|c|}{ Yield $(\%)^{\mathrm{b}}$} \\
\hline & & 1 & 2 & 3 & 1 & 2 & 3 & 1 & 2 & 3 \\
\hline 1 & & 92 & 87 & 89 & 12 & 11 & 11 & 92 & 87 & 89 \\
\hline 2 & & 88 & 79 & 82 & 11 & 10 & 10 & 88 & 79 & 82 \\
\hline 3 & & 84 & 78 & 82 & 11 & 10 & 10 & 84 & 78 & 82 \\
\hline 4 & & 76 & 68 & 71 & 10 & 9 & 9 & 76 & 68 & 71 \\
\hline 5 & & 81 & 73 & 79 & 10 & 9 & 10 & 81 & 73 & 79 \\
\hline 6 & & 93 & 81 & 89 & 12 & 10 & 11 & 93 & 81 & 89 \\
\hline 7 & & 88 & 78 & 81 & 11 & 10 & 10 & 88 & 78 & 81 \\
\hline 8 & $\mathrm{O}$ & 72 & 63 & 69 & 9 & 8 & 9 & 72 & 63 & 69 \\
\hline
\end{tabular}

aReaction conditions: $1 \mathrm{mmol}$ of alcohol, $1.2 \mathrm{mmol}$ of amine, $\mathrm{NaH}(5 \mathrm{~mol} \%)$, catalyst (1 mol \%) in $3 \mathrm{~mL}$ of toluene.

${ }^{\mathrm{b}}$ Yields were calculated after isolation of the amide product through short column chromatography using silica gel (100-200 mesh).

${ }^{\mathrm{c}}$ Molar ratios of product formed with the catalyst used.

${ }^{\mathrm{d}} \mathrm{TOF}=\mathrm{TON} / \mathrm{time}(\mathrm{h})$ 
alcohol with different amines gave the corresponding amides (entry 5-8) with 71-94\% yields,. Electron-rich $p$-methoxybenzyl alcohol also afforded good to excellent yields of corresponding amides with benzylamine (entry 9), p-methylbenzylamine (entry 10), cyclohexylamine (entry 11) and aniline (entry 12) under optimized conditions. Electron-deficient $p$-fluorobenzyl alcohol gave relatively lower yields compared to electron rich alcohols (entry 13). Furthermore, hexanol afforded lesser yield when treated with benzylamine and aniline (entry 14, 15). The data provide several insights regarding the identity of successful catalysts. Gratifyingly, all the reactions proceeded efficiently and furnished all types of substituted amides in good to excellent yields.

\section{5 [Ru-NHC] catalyzed amide syntheses from alcohols and secondary amines}

Next, various secondary amines were tested for the amidation reactions (table 5). To our delight, all the complexes showed better activity for secondary amines with moderate to good yields. The reaction of 2-phenylethanol and benzyl alcohol with piperidine afforded the products in reasonable to good yields upon isolation (entry 1,3). Similarly, morpholine undergoes amidation successfully with benzyl alcohol to furnish excellent yields in $8 \mathrm{~h}$ (entry 2). The reaction of 2-phenyl ethanol with benzylmethylamine gave $N$-benzyl- $N$-methyl-2phenyl acetamide in $68-76 \%$ yields (entry 4 ). The coupling of benzyl alcohol and p-methoxybenzyl alcohol with benzylmethylamine yielded the corresponding amide in good yields (entry 5, 6). The results indicated that electron withdrawing substituents on aromatic ring alcohol were converted to corresponding amides with benzylmethylamine in good isolated yield of $79-89 \%$ (entry 7). The formation of $N, N$-dibenzyl-2-phenyl acetamide from 2-phenyl ethanol was easily coupled with dibenzylamine and was isolated in $63-72 \%$ yield (entry 8).

\subsection{Mechanism}

The precise reaction mechanism is yet to be elucidated. Nevertheless, a few comments can be made. We believe that the catalytic amidation with [Ru-NHC] complexes follows the " $\beta$-hydride elimination" pathway, extensively studied by Milstein et al. ${ }^{34}$ The reaction was proceeded by initial dehydrogenation of the alcohol to the aldehyde, which stays coordinated to ruthenium. The aldehyde generated from the alcohol stays coordinated to the metal is valid for the facile formation of amide.
Subsequent attack by the amine affords the hemiaminal which also stays coordinated to the metal. The amide is then formed after $\beta$-hydride elimination. ${ }^{23 a, 35}$ This classical mechanism is proposed by several workers on the studies of metal complex catalyzed coupling of alcohol and amine to produce amide. ${ }^{18-21}$

The catalytic activities of complexes 1-3 are comparable with the previously reported catalyst systems. ${ }^{18,19}$ Our catalytic system showed comparable or a slightly improved activity when compared with Madsen's system under basic conditions, and the turn over numbers (TONs) are less than those of Milstein's catalyst under neutral conditions. Our method is also advantageous because of the mild reaction conditions, low catalyst loadings, functional group tolerance, simple protocols and easy workup without any additives. ${ }^{22-24}$

Although the complete elucidation of the mechanism has not been undertaken, we have conducted some control experiments to ascertain the specific role of the catalyst and exact nature of the catalytic intermediate for these novel amidation reactions. Efforts are underway to elucidate the mechanistic details of these $\mathrm{NH}$ bond forming reactions.

\section{Conclusions}

In this paper, we report the design and preparation ruthenium(II) complexes (1-3) bearing bis-phenolate$\mathrm{N}$-heterocyclic carbene ligands in two consecutive steps. The ruthenation was accomplished by metallation with $\mathrm{Ag}_{2} \mathrm{O}$ to form intermediate silver carbene complexes and subsequent transmetalation with $\left[\mathrm{RuHCl}(\mathrm{CO})\left(\mathrm{EPh}_{3}\right)_{2}(\mathrm{~B})\right]\left(\mathrm{E}=\mathrm{P}\right.$ or $\mathrm{As} ; \mathrm{B}=\mathrm{PPh}_{3}$, $\mathrm{AsPh}_{3}$ or Py). The yields were promising. The [RuNHC] complexes (1-3) displayed excellent stability toward air and moisture which are the additional advantages for a better catalyst. Spectral data for these $\mathrm{Ru}$ complexes suggest that this tridentate NHC-bisaryloxide ligand may significantly crowd the sphere of coordination of the Ru metal center. The catalytic study of complexes 1-3 towards amidation of alcohol with amines completed, showing that all catalysts are active toward this catalytic transformations. The reaction progresses efficiently at low catalyst loading (1 mol \% of 1-3). This new protocol is effective for many electronically diverse alcohols and amines, providing corresponding amide derivatives in good to excellent yields. Efforts are currently underway in our research group to expand the scope of this method to a library of different functionalized substrates with even greater activity and elucidation of mechanistic principles underlying these novel amidation reactions. 


\section{Supporting Information}

Representative NMR $\left({ }^{1} \mathrm{H},{ }^{13} \mathrm{C},{ }^{31} \mathrm{P}\right)$ and ESI-MS spectra of ligand and complexes (figures S1-S10), detailed experimental procedure, spectral data and selected ${ }^{1} \mathrm{H}$ and ${ }^{13} \mathrm{C}$ NMR spectra for amide products (figures S11S18) are given in the supporting information available at www.ias.ac.in/chemsci.

\section{Acknowledgements}

The authors express their sincere thanks to Science and Engineering Research Board (SERB), Department of Science and Technology, New Delhi, for financial support for this work under the DST FAST TRACK Scheme (No. SR/FT/CS-66/2011). One of the authors (MN) thanks DST-SERB for the award of fellowship.

\section{References}

1. For reviews, see: (a) Melaimi M, Soleilhavoup M and Bertrand G 2010 Angew. Chem. Int. Ed. 49 8810; (b) Poyatos M, Mata J A and Peris E 2009 Chem. Rev. 109 3677; (c) Hahn F E and Jahnke M C 2008 Angew. Chem. Int. Ed. 47 3122; (c) Herrmann W A 2002 Angew. Chem. Int. Ed. 41 1290; (h) Kumar A and Ghosh P 2012 Eur. J. Inorg. Chem. 3955; (d) Wang F, Liu L J, Wang W, Li S and Shi M 2012 Coord. Chem. Rev. 256 804; (e) Boyarskiy V P, Luzyanin K V and Kukushin V Y 2012 Coord. Chem. Rev. 2562029

2. (a) Bantreil X, Schmid T E, Randall R A M, Slawin A M Z and Cazin C S J 2010 Chem. Commun. 46 7115; (b) Scholl M, Ding S, Lee W and Grubbs R H 1999 Org. Lett. 1953

3. Samojlowicz C, Bieniek M and Grela K 2009 Chem. Rev. 1093708

4. (a) Vicent C, Viciano M, Mas-Marza E, Sanau M and Peris E 2006 Organometallics 25 3713; (b) Poyatos M, Maisse-Francois A, Bellemin-Laponnaz S and Gade L H 2006 Organometallics 25 2634; (c) Lu C, Gu S, Chen W and Qiu H 2010 Dalton Trans. 39 4198; (d) Berding J, Lutz M, Spek A L and Bouwman E 2009 Organometallics 281845

5. Nirmala $M$, Prakash G, Ramachandran $R$, Viswanathamurthi P, Malecki J G and Linert W $2015 \mathrm{~J}$. Mol. Catal. A: Chem. 39756

6. Nirmala M, Prakash G, Viswanathamurthi $P$ and Malecki J G 2015 J. Mol. Catal. A: Chem. 40315

7. (a) Yamaguchi $\mathrm{K}$, Kobayashi $\mathrm{H}$, Wang $\mathrm{Y}$, Oishi $\mathrm{T}$, Ogasawara Y and Mizuno N 2013 Catal. Sci. Technol. 3 318; (b) Chen C and Hyeok Hong S 2011 Org. Biomol. Chem. 9 20; (c) Carey J S, Laffan D, Thomson C and Williams M T 2006 Org. Biomol. Chem. 42337

8. (a) Han S Y and Kim Y A 2004 Tetrahedron 60 2447; (b) Montalbetti C A G N and Falque V 2005 Tetrahedron 61 10827; (c) Valeur E and Bradley M 2009 Chem. Soc. Rev. 38 606; (d) Larock R C 1999 In Comprehensive Organic Transformations (New York: $\mathrm{VCH}$ )
9. (a) Saxon E and Bertozzi C R 2000 Science 287 2007; (b) Damkaci F and DeShong P $2003 \mathrm{~J}$. Am. Chem. Soc. 125 4408; (c) Gololobov Y G and Kasukhin L F 1992 Tetrahedron 481353

10. (a) Ribelin T, Katz C E, English D G, Smith S, Manukyan A K, Day V W, Neuenswander B, Poutsma J L and Aub J 2008 Angew. Chem. Int. Ed. 120 6329; (b) Lang S and Murphy J A 2006 Chem. Soc. Rev. 35146

11. (a) Owston N A, Parker A J and Williams J M J 2007 Org. Lett. 93599 ; (b) Hashimoto M, Obora Y, Sakaguchi S and Ishii Y 2008 J. Org. Chem. 732894

12. (a) Martinelli J R, Clark T P, Watson D A, Munday R H and Buchwald S L 2007 Angew. Chem. 119 8612; (b) Nanayakkara P and Alper H 2003 Chem. Commun. 2384

13. Beller M, Cornils B and Frohning C D $1995 \mathrm{~J} . \mathrm{Mol}$. Catal. A: Chem. 10417

14. (a) Ali B E and Tijani J 2003 Appl. Organomet. Chem. 17 921; (b) Knapton D J and Meyer T Y 2004 Org. Lett. 6 687; (c) Uenoyama Y, Fukuyama T, Nobuta O, Matsubara H and Ryu I 2005 Angew. Chem. 117 1099; (d) Park J H, Kim S Y, Kim S M and Chung Y K 2007 Org. Lett. 92465

15. (a) Chang J W W and Chan P W H 2008 Angew. Chem. 120 1154; (b) Yoo W J and Li C J 2006 J. Am. Chem. Soc. 128 13064; (c) Cho S, Yoo E, Bae I and Chang S 2005 J. Am. Chem. Soc. 12716046

16. (a) Kolakowski R V, Shangguan N, Sauers R R and Williams L J 2006 J. Am. Chem. Soc. 128 5695; (b) Zhang X, Li F, Lu X W and Liu C F 2009 Bio. Conjugate Chem. 20197

17. (a) Anastas P and Eghbali N 2010 Chem. Soc. Rev. 39 301; (b) Constable D J C, Dunn P J, Hayler J D, Humphrey J R, Leazer J J L, Linderman R J, Lorenz K, Manley J, Pearlman B A, Wells A, Zaks A and Zhang T Y 2007 Green. Chem. 9411

18. (a) Gunanathan C, Ben-David Y and Milstein D 2007 Science 317 790; (b) Naota T and Murahashi S I 1991 Synlett 693; (c) Prechtl M H G, Wobser K, Theyssen N, David Y B, Milstein D and Leitner W 2012 Catal. Sci. Technol. 2 2039; (d) Lanigan R M and Sheppard T D 2013 Eur. J. Org. Chem. 33 7453; (e) Ghosh S C and Hong S H 2010 Eur. J. Org. Chem. 4266; (f) Herrmann W A, Elison M, Fischer J, Kocher C and Artus G R J 1995 Angew. Chem. Int. Ed. Engl. 34 2371; (g) Herrmann W A and Kocher C 1997 Angew. Chem. Int. Ed. 36 2163; (h) Bourissou D, Guerret O, Gabbai F P and Bertrand G 2000 Chem. Rev. 100 39; (i) Hahn F E 2006 Angew. Chem. Int. Ed. 45 1348; (j) Semeril D, Bruneau C and Dixneuf P H 2002 Adv. Synth. Catal. 344 585; (k) Dupont J and Spencer 2004 J. Angew. Chem. Int. Ed. 43 5296; (1) Iglesias $\mathrm{M}$ and Albrecht M 2010 Dalton Trans. 39 5213; (m) Araki S, Yokoi K, Sato R, Hirashita T and Setsune J J 2009 Heterocycl. Chem. 46 164; (n) Guisado-Barrios G, Bouffard J, Donnadieu B, Bertrand G 2010 Angew. Chem. Int. Ed. 49 4759; (o) Lalrempuia R, McDaniel N D, Muller-Bunz H, Bernhard S and Albrecht M 2010 Angew. Chem. Int. Ed. 499765

19. (a) Nørdstrom L U, Vogt H and Madsen R $2008 \mathrm{~J}$. Am. Chem. Soc. 130 17672; (b) Watson A J A, Maxwell A C and Williams J M J 2009 Org. Lett. 11 2667; (c) Ghosh S C, Muthaiah S, Zhang Y, Xu X and Hong S H 2009 Adv. 
Synth. Catal. 351 2643; (d) Zhang Y, Chen C, Ghosh S C, Li Y and Hong S H 2010 Organometallics 29 1374

20. (a) Fujita K, Takahashi Y, Owaki M, Yamamoto K and Yamaguchi R 2004 Org. Lett. 6 2785; (b) Zweifel T, Naubron J V and Grutzmacher H 2009 Angew. Chem. Int. Ed. 48559

21. Shimizu K, Ohshima K and Satsuma A 2009 Chem. Eur. J. 159977

22. (a) Dam J H, Osztrovszky G, Nordstrøm L U and Madsen R 2010 Chem. Eur. J. 16 6820; (b) Makarov I S, Fristrup P and Madsen R 2012 Chem. Eur. J. 18 15683; (c) Maggi A and Madsen R 2012 Organometallics 31 451; (d) Sølvhøj A and Madsen R 2011 Organometallics 306044

23. (a) Watson A J A, Maxwell A C and Williams J M J 2009 Org. Lett. 11 2667; (b) Allen C L and Williams J M J 2011 Chem. Soc. Rev. 40 3405; (c) Allen C L, Chhatwal A R and Williams J M J 2012 Chem. Commun. 48 666; (d) Hamid M H S A, Allen C L, Lamb G W, Maxwell A C, Maytum H C, Watson A J A and Williams J M J 2009 J. Am. Chem. Soc. 131 1766; (e) Watson A J A and Williams J M J 2010 Science 329635

24. (a) Ghosh S C, Muthaiah S, Zhang Y, Xu X and Hong S H 2009 Adv. Synth. Catal. 351 2643; (b) Muthaiah S, Ghosh S C, Jee J E, Chen C, Zhang J and Hong S H 2010 J. Org. Chem. 75 3002; (c) Zhang Y, Chen C, Ghosh S C, Li Y and Hong S H 2010 Organometallics 29 1374; (d) Chen C and Hong S H 2011 Org. Biomol. Chem. 9 20; (e) Fu Z, Lee J, Kang B and Hong S H 2012 Org. Lett. 14 6028; (f) Fu Z, Lee J, Kang B and Hong S H 2012 Org. Lett. 14 6028; (g) Yaşar S, Çekirdek S and Özdemir I 2014 J. Coord. Chem. 671236

25. Ahmed N, Levison J J, Robinson S D and Uttley M F 1974 Inorg. Synth. 1545
26. Sanchez-Delgado R A, Lee W Y, Choi S R, Cho Y and Jun M J 1991 Trans. Met. Chem. 16241

27. Gopinathan S, Unny I R, Deshpande S S and Gopinathan C 1986 Ind. J. Chem. A. 251015

28. (a) Min K S, Weyhermuller T, Bothe E and Wieghardt K 2004 Inorg. Chem. 43 2922; (b) Bellemin-Laponnaz S, Welter R, Brelot L and Dagorne S J 2009 J. Organomet. Chem. 694604

29. (a) $\mathrm{Hu} \mathrm{X}$, Castro-Rodriguez I, Olsen $\mathrm{K}$ and Meyer K 2004 Organometallics 23 755; (b) Herrmann W A, Schneider S K, Ofele K, Sakamoto M and Herdtweck E 2004 J. Organomet. Chem. 689 2441; (c) Mayr M, Wurst K, Ongania K H and Buchmeiser M R 2004 Chem. Eur. J. 101256

30. Waltman A W and Grubbs R H 2004 Organometallics 233105

31. (a) Csabai P and Joo F 2004 Organometallics 23 5640; (b) Lemke J and Metzler-Nolte N 2008 Eur. J. Inorg. Chem. 21 3359; (c) Maishal T K, Basset J M, Boualleg M, Coperet C, Veyre L and Thieuleux C 2009 Dalton Trans. 356956

32. Pozo C D, Iglesias M and Sanchez F 2011 Organometallics $\mathbf{3 0} 2180$

33. (a) Poyatos M, Mas-Marza E, Sanau M and Peris E 2004 Inorg. Chem. 43 1793; (b) Buchmeiser M R, Wang D, Zhang Y, Naumov S and Wurst K 2007 Eur. J. Inorg. Chem. 3988; (c) Baya M, Eguillor B, Esteruelas M A, Olivan M and Onate E 2007 Organometallics 26 6556; (d) Poyatos M, McNamara W, Incarvito C, Clot E, Peris E and Crabtree R H 2008 Organometallics 27 2128; (e) Ghattas W, Muller-Bunz H and Albrecht M 2010 Organometallics 296782

34. Gnanaprakasam B and Milstein D $2011 \mathrm{~J}$. Am. Chem. Soc. 1331682

35. Xie X and Huynh H V 2015 ACS Catal. 54143 